\title{
Immunological features of lung lavage cells from patients with primary biliary cirrhosis may reflect those seen in pulmonary sarcoidosis
}

\author{
M A Spiteri, M Johnson, O Epstein, S Sherlock, S W Clarke, L W Poulter
}

\begin{abstract}
To investigate the basis of subclinical alveolitis in patients with primary biliary cirrhosis, 10 primary biliary cirrhosis patients were studied by bronchoalveolar lavage. Both bronchoalveolar lavage lymphoid and non-lymphoid cell populations were analysed using immunocytological methods to determine their proportions and phenotypic features in an attempt to gain information as to possible immune mechanisms active in the lung of these patients. Six of the 10 patients in our study showed evidence of an alveolitis (raised lymphocyte count: $27 \cdot 6(4 \cdot 3) \%$ of total count) on lavage. The results were compared with control groups of normal volunteers and patients with active pulmonary sarcoidosis. The six primary biliary cirrhosis patients with lymphocytosis had a raised CD4/CD8 T-cell ratio (4.13:1), similar to the sarcoid patients (5.60:1). A proportion of these T-lymphocytes expressed markers of activation (HLA-DR+ $7.5(2 \cdot 1) \%) ; \quad C D 25+2.3 \quad(0.9) \% ; \quad C D 7+5.8$ $(1 \cdot 5) \%$. This increased $\mathrm{T}$-cell activation was also seen in the sarcoid groups (HLA-DR+ $10.0(1.9) \%$; CD25+3.0 (1.1)\%; CD7+5.0 $(0 \cdot 2) \%)$. This was not seen in the primary biliary cirrhosis patients without lymphocytosis and the normal volunteers. Within the non-lymphoid cell population, an increase in dendritic (RFD1 + ) cells was seen in primary biliary cirrhosis patients with lymphocytosis $(31 \cdot 2(1.9) \%)$ and sarcoid patients $(46 \cdot 3(5 \cdot 1) \%)$ in contrast with the normal and primary biliary cirrhosis group without lymphocytosis. The primary biliary cirrhosis patients without lymphocytes had a relatively greater proportion of mature phagocytes $($ RFD7 + ). We postulate that these observations suggest the emergence in the lung of a granuloma producing mechanism similar to that occurring in the liver. By comparison, the alveolitis found in primary biliary cirrhosis is consistent with that observed in interstitial granulomatous lung disorders such as sarcoidosis.
\end{abstract}

Thoracic Medicine Medical Unit $†$ and Immunologył, Royal Free Hospital and School of Medicine, London M A Spiteri*

M Johnson ${ }^{\star}$

O Epsteint

S Sherlockt

$S$ W Clarke

L W Poulterł

Address for correspondence: Dr L W Poulter, Department of Immunology, The Royal Free Hospital, Pond Street London NW3 2QG

Accepted for publication 8 May 1989 hepatic bile ducts with eventual portal fibro and cirrhosis. 'The rate at which the progresses varies considerably, producing a wide clinical spectrum. ${ }^{2}$ Raised serum bilirubin concentrations reflect a poor prognosis, ${ }^{3}$ while patients with focal granulomatous lesions in their livers have a better prognosis. ${ }^{+}$Factors determining this disease progression are ill under-
Primary biliary cirrhosis is a chronic progressive stood. A number of abnormalities of the immune system have been described in primary biliary cirrhosis, ${ }^{56}$ but whether these arise as a consequence of the liver disease or whether they are implicated in either the initiation or progression of the disease process remains unclear.

The true incidence of pulmonary complications in patients with primary biliary cirrhosis is unknown; however, the possible involvement of the lung during the course of primary biliary cirrhosis is acknowledged. ${ }^{7-9}$ Observations range from reports of associated fibrosing alveolitis ${ }^{8}$ to the presence of parenchymal granulomata mimicking pulmonary sarcoidosis. ${ }^{9}$ Radiological parenchymal shadowing and lung function defects (reduced diffusion capacity and airways obstruction) have also been cited. ${ }^{10}$ The significance of such associations remains controversial, with some authors suggesting that the radiological lung shadowing and defective pulmonary function in primary biliary cirrhosis are secondary to pulmonary vascular disorders rather than coincidental interstitial disease." Recently Wallaert et $a l^{12}$ observed the presence of alveolitis in primary biliary cirrhosis patients with normal chest radiographs and lung function. The alveolitis was characterised by increased number of T-helper lymphocytes in the bronchoalveolar lavage of these patients, indicating that immunological abnormalities may coexist in the lung in primary biliary cirrhosis. It is now recognised that such an alveolitis is often an early manifestation of interstitial lung disease, independent of the type of condition or specific aetiology involved. ${ }^{1314}$ Moreover, subclinical inflammatory processes of the lower respiratory tract have been detected in asymptomatic patients with various disorders - for example sarcoidosis, Crohn's disease, rheumatoid arthritis - long before interstitial pulmonary reactions become clinically evident. ${ }^{15}$ Although sarcoidosis and primary biliary cirrhosis are thought of as distinct granulomatous disorders, many overlapping features (clinical, histological and immunological) are present in both.

It is recognised that in granulomatous disorders both the $\mathrm{T}$-cell activation and the granuloma formation are controlled by macrophage like cells. ${ }^{16}$ In addition, considerable phenotypic and functional heterogeneity exist within the macrophage population. ${ }^{17} 18 \mathrm{It}$ would therefore be essential that in order to characterise the alveolitis in primary biliary cirrhosis patients, both the lymphoid and nonlymphoid cell populations must be studied. Bronchoalveolar lavage offers the possibility of assessing the emergence of the subclinical alveolitis in patients with primary biliary 
cirrhosis and allows monoclonal antibodies to be used as probes to define the state of activation and immunocompetence of the cell subsets involved in the inflammatory process. Such studies would help to reveal the underlying immunological reactions occurring in the lungs of patients with primary biliary cirrhosis. In addition, the evaluation of the relationship of these findings to those documented from cases of other well known granulomatous disorders such as sarcoidosis would benefit the management of those primary biliary cirrhosis patients in whom the alveolitis progresses and becomes symptomatic.

\section{Methods}

\section{SUBJECTS}

The study population consisted of 10 patients with biopsy proven primary biliary cirrhosis (diagnosis $>1$ year; no evidence of associated autoimmune diseases): eight women, two men; mean age 46 years, two smokers (one pack/day). All were asymptomatic as regards their chest, with normal chest radiographs and lung function parameters (forced expiratory volume in 1 second, forced vital capacity, total lung capacity and transfer factor). None of the patients were receiving any immunosuppressive therapy at the time of the study. All primary biliary cirrhosis patients had been screend by serological tests for other immunological disorders and found to be negative. Prognostic staging of primary biliary cirrhosis was assessed by serum bilirubin concentrations ${ }^{3}$ and histological analysis of liver biopsies. ${ }^{+}$Fifteen patients with biopsy proven pulmonary sarcoidosis were recruited; all nonsmokers; 12 men, three women; mean aged 38 years. All had abnormal chest radiographs ranging from bilateral hilar lymphadenopathy (five patients) to hilar lymphadenopathy with interstitial shadowing (four) to interstitial shadowing alone (six). None were receiving any form of treatment at the time of investigation. A population of 10 healthy controls: non-smokers; nine men, one woman, mean age 22 years. All had normal chest radiographs and pulmonary function. Although not directly matched for age and sex, in over 150 subjects lavaged we have observed no bearing of age and sex on bronchoalveolar lavage cell phenotype. None of the normal volunteers and primary biliary cirrhosis patients had a past history of lung disease or any viral illness in the preceding two weeks. All subjects in the study gave formal consent before participation. In addition, this study had the full support of the local Ethics Committee.

\section{BRONCHOALVEOLAR LAVAGE}

Bronchoalveolar lavage was performed using a fibreoptic bronchoscope. The right middle lobe was anaesthetised with $2 \%$ lidocaine and lavaged with $20 \mathrm{ml}$ aliquots to a total of $180 \mathrm{ml}$ of $0.9 \%$ normal saline (buffered with $\mathrm{NaHCO}_{3}$ to $\mathrm{pH}$ $7 \cdot 4)$. The lavage fluid was gently aspirated after each aliquot and collected into a sterile siliconised glass bottle maintained at $4^{\circ} \mathrm{C}$.

\section{PROCESSING OF SAMPLES}

The lavage fluid was filtered through a coarse gauze and centrifuged at $480 \mathrm{G}$, at $4^{\circ} \mathrm{C}$. The cell pellet was then washed twice in RPMI 1640 medium and finally resuspended in supplemented RPMI 1640 (containing 1.25\% $200 \mathrm{nmol} \mathrm{L}$-glutamine, $10 \%$ heat inactivated fetal calf serum, $100 \mu \mathrm{g} / \mathrm{ml}$ streptomycin and 100 $\mathrm{IU} / \mathrm{ml}$ penicillin). The bronchoalveolar lavage cells were counted in a modified Neubauer haemocytometer and viability assessed by cellular exclusion of trypan blue. This was found to be greater than $90 \%$ in each case.

\section{IMMUNOCY TOLOGICAL ANALYSIS}

The bronchoalveolar lavage concentration was adjusted to $3 \times 10^{5}$ cells $/ \mathrm{ml}$, and cytospins prepared using $100 \mu \mathrm{l}$ aliquots. One cytospin was stained for morphology to facilitate differential cell counting; the remainder were air dried for one hour at room temperature, fixed in 1:1 mixture of chloroform: acetone for 10 minutes, wrapped in plastic film and stored at $-20^{\circ} \mathrm{C}$ until use. Cytospin preparations were later incubated with a panel of monoclonal antibodies (McAb) (Table I). To discriminate particular macrophage subsets involved in the inflammatory process, the macrophage markers RFD1, RFD7 and RFD9 were used. T-lymphocyte subpopulations were identified using McAbs OKT4 and RFT8. The state of activation of such lymphocytes was analysed with RFDR, CD25 and CD7 (the latter

TABLE I Monoclonal antibodies used in this study

\begin{tabular}{|c|c|c|c|c|c|}
\hline Antibody & $\begin{array}{l}\text { Cluster } \\
\text { designation }\end{array}$ & Antigen (mol wt) & Source & $\begin{array}{l}\text { Specificity in } \\
\text { normal tissue }\end{array}$ & Reference \\
\hline RFDR I & - & $28 / 33 \mathrm{KD}$ & RFHSM & $\begin{array}{l}\text { Framework epitope on } \\
\text { HLA-DR molecule }\end{array}$ & 19 \\
\hline RFD1 & - & $28 / 33 \mathrm{KD}$ & RFHSM & $\begin{array}{l}\text { Interdigitating cells; } \\
\text { small proportion B cells }\end{array}$ & 20 \\
\hline $\begin{array}{l}\text { RFD7 } \\
\text { RFD9 }\end{array}$ & $\begin{array}{l}- \\
-\end{array}$ & $\begin{array}{l}77 \mathrm{KD} \\
-\end{array}$ & $\begin{array}{l}\text { RFHSM } \\
\text { RFHSM }\end{array}$ & $\begin{array}{l}\text { Mature macrophages } \\
\text { Epithelioid cells; } \\
\text { tingible body Mø }\end{array}$ & $\begin{array}{l}20 \\
21\end{array}$ \\
\hline $\begin{array}{l}\text { OKT4 } \\
\text { RFT8 } \\
\text { RFT2 }\end{array}$ & $\begin{array}{l}\text { CD4 } \\
\text { CD8 } \\
\text { CD7 }\end{array}$ & $\begin{array}{l}62 \mathrm{KD} \\
30-32 \mathrm{KD} \\
40 \mathrm{KD}\end{array}$ & $\begin{array}{l}\text { Ortho } \\
\text { RFHSM } \\
\text { RFHSM }\end{array}$ & $\begin{array}{l}\text { Helper-inducer T-cells } \\
\text { Suppressor-cytotoxic T-cells } \\
\text { PAN-T; preferentially } \\
\text { expressed on blast cells }\end{array}$ & $\begin{array}{l}22 \\
23 \\
24\end{array}$ \\
\hline $\begin{array}{l}\text { Anti-tac } \\
\text { SN130 }\end{array}$ & $\begin{array}{l}\text { CD25 } \\
\text { CD45R }\end{array}$ & $\begin{array}{l}53 \mathrm{KD} \\
200-220 \mathrm{KD}\end{array}$ & $\begin{array}{l}\text { DAKO } \\
\text { RFHSM }\end{array}$ & $\begin{array}{l}\text { IL-2 receptors } \\
\text { Recognise distinct isoforms of } \\
\text { the leucocyte common antigen }\end{array}$ & $\begin{array}{l}25 \\
26\end{array}$ \\
\hline UCHLl & - & $180 \mathrm{KD}$ & $\begin{array}{l}\text { P Beverley } \\
\text { (Middlesex Hosp) }\end{array}$ & & 27 \\
\hline
\end{tabular}


acting only as an activation marker at a dilution of 1 in 5). In addition, McAbs UCHLl and SN130 were used as probes to investigate the immunological competence of the cell subsets involved in the alveolitis. In order to identify these individual cell surface antigens the immunoperoxidase method ${ }^{28}$ was used, incorporating D-aminobenzidine $(0.125 \mathrm{ml})$ and hydrogen peroxide $(5 \mu \mathrm{l})$ in Tris hydrogen chloride $(5 \mathrm{ml}, \mathrm{pH} 7 \cdot 6,0 \cdot 05 \mathrm{M})$ as the developing solution. The positive cells were identified using an Olympus light microscope with high magnification (x 600). Background staining was identified by comparison with negative control cytospins on which the McAb was omitted; positive specificity controls were prepared using sections of human palatine tonsil. At least 150 cells were counted in each cytospin, and the percentage of positive cells recorded.

STATISTICAL ANALYSIS

Where relevant, data were analysed using the Students' $T$ test for non-paired data.

\section{Results}

BRONCHOSCOPIC FINDINGS

No evidence of any bronchial infection or inflammation was found in any subject. There was no significant difference in percentage return of lavage fluid in any of the groups (mean $72 \cdot 0(11 \cdot 0) \%$ of instilled volume $)$.

DIFFERENTIAL CELL COUNTS (Fig 5)

The mean proportion of lymphocytes in bronchoalveolar lavage patients with primary

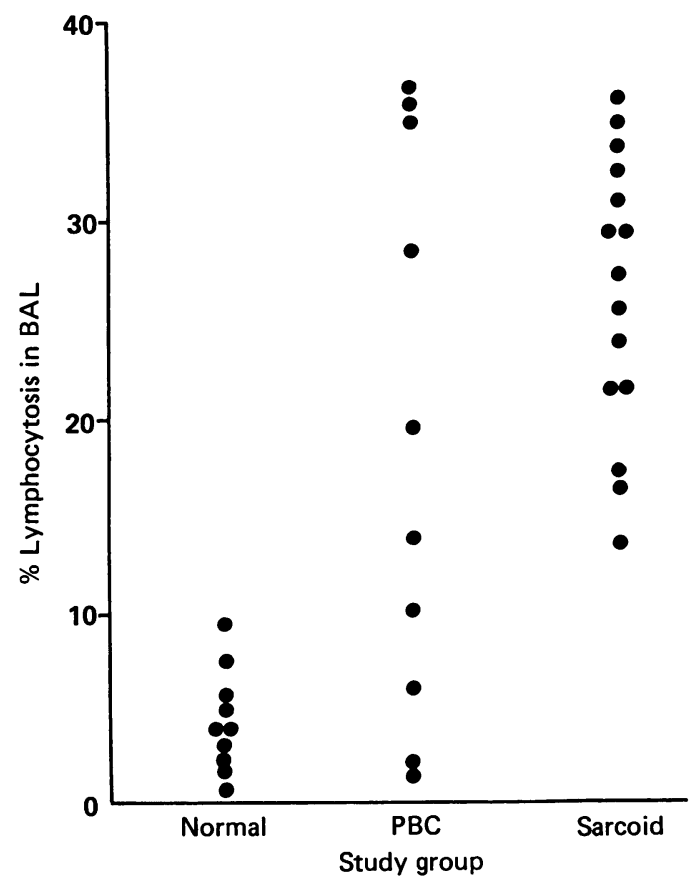

Figure: The above represents the percentage of morphologically identifiable lymphocytes in the bronchoalveolar lavage of each subject investigated. In comparison to the normal volunteers, lymphocyte proportions in bronchoalveolar lavage were significantly higher in both primary biliary cirrhosis patients $(p<0.01)$ and sarcoid patients $(p<0.0001)$
TABLE II Percentage proportion and distribution of $T$ lymphocytes within bronchoalveolar lavage of primary biliary cirrhosis, sarcoid and normal subjects

\begin{tabular}{|c|c|c|}
\hline & $\% T$-cells & CD4: $C D 8$ \\
\hline Primary biliary cirrhosis & $95 \cdot 8(3.5)$ & $4.13: 1^{\star}$ \\
\hline $\begin{array}{l}\text { Primary biliary cirrhosis } \\
\text { with lymphocytosis }(n=4)\end{array}$ & $83.7(10 \cdot 8)$ & $1 \cdot 60: 1$ \\
\hline $\begin{array}{l}\text { Normal volunteers }(n=10) \\
\text { Sarcoid }(n=15)\end{array}$ & $\begin{array}{l}89 \cdot 2(7 \cdot 3) \\
97 \cdot 0(1 \cdot 2)\end{array}$ & $\begin{array}{l}1.80: 1 \\
5 \cdot 60: 1^{\star}\end{array}$ \\
\hline
\end{tabular}

${ }^{\star} \mathrm{p}=<0.001$ compared with normal.

The proportion of $\mathrm{B}$-cells was consistently $<1 \%$ in each group

biliary cirrhosis was raised when compared to normal $(\mathrm{p}<0 \cdot 01)$. The difference resulted from the fact that six of the 10 patients with primary biliary cirrhosis had markedly raised proportions of lymphocytes in bronchoalveolar lavage (mean (SE) $27 \cdot 6(4 \cdot 3) \%$ of total count) compared with normal $(5 \cdot 0(3 \cdot 4) \%)$. The other four primary biliary cirrhosis patients had the same lymphocyte proportions $(4.8(2.4) \%)$ as the normal volunteers. All patients with pulmonary sarcoidois had a marked lymphocytosis $(29 \cdot 2$ $(4 \cdot 1) \%)$ in their bronchoalveolar lavage. The six primary biliary cirrhosis patients with lymphocytosis had a raised total cell count in bronchoalveolar lavage $\left(1.43(0.67) \times 10^{6} \mathrm{cells} /\right.$ $\mathrm{ml})$ as did the sarcoid group $\left(1.66(0.3) \times 10^{6} / \mathrm{ml}\right)$, in contrast to the other four primary biliary cirrhosis patients and normal volunteers $(0.52$ $\left(0.14 \times 10^{6} / \mathrm{ml}\right.$ and $0.71(0.2) \times 10^{6} / \mathrm{ml}$ respectively). Macrophage proportions were thus altered accordingly being lower than normal in those six primary biliary cirrhosis patients with lymphocytosis, and normal in the four primary biliary cirrhosis patients without lymphocytosis. The raised total cell yield in primary biliary cirrhosis patients with lymphocytosis meant however that actual numbers of macrophages harvested was not reduced.

IMMUNOCYTOLOGICAL ANALYSIS

In all subjects, over $83 \%$ of lymphocytes in bronchoalveolar lavage were T-cells; of which more than $82 \%$ expressed UCHLl (Tables II and III). There was no significant difference between any of the groups. A marked increase in CD4/ CD8 $\mathrm{T}$-cell ratio was seen in the group of primary biliary cirrhosis patients with lymphocytosis (4.13:1) and sarcoid patients (5.60:1), compared with normal (1.80:1) and primary biliary cirrhosis patients without lymphocytosis (1.60:1) (Table II). A small proportion of Tlymphocytes expressed markers of activation being positive with RFDR1, CD7 and CD25. McAbs both in PBC patients with evidence of lymphocytosis $(7 \cdot 5(2 \cdot 1) \%, 5 \cdot 8(1 \cdot 5) \%, 2 \cdot 3$ $(0.9) \%$ respectively) and in the sarcoid groups $(10.0(1.9) \%, 5.0(0.2) \%, 3.0(1.1) \%$ respectively). This was not seen in the other two groups (Table III).

Within the non-lymphoid cell population, an increase in proportion of RFD1+ cells was seen in primary biliary cirrhosis patients with lymphocytosis $(31.2)(1.9) \%)$ and sarcoid patients $(46 \cdot 3(5 \cdot 1) \%$ in contrast with the normal $(13.6(2 \cdot 1) \%$ and the PBC group without lymphocytosis $(6.5 \quad(1 \cdot 1) \%$. No significant difference was seen in the proportion of RFD9+ 
TABLE III Phenotypic characteristics of lavage T-lymphocytes in each group

\begin{tabular}{|c|c|c|c|c|c|}
\hline & $S N 130^{\star}$ & $U C H L 1^{\star}$ & $H L A-D R^{\star}$ & $C D 7^{\star}$ & $C D 25^{\star}$ \\
\hline $\begin{array}{l}\text { Primary biliary cirrhosis } \\
\text { with lymphocytosis }(n=6)\end{array}$ & $0 \cdot 60(0 \cdot 4)$ & $97 \cdot 3(0 \cdot 6)$ & $7 \cdot 5(2 \cdot 3)^{\star}$ & $5 \cdot 8(1 \cdot 7)^{\star}$ & $2 \cdot 2(1 \cdot 1) \dagger$ \\
\hline $\begin{array}{l}\text { with lymphocytosis }(n=6) \\
\text { Primary biliary cirrhosis } \\
\text { without lymphocytosis }(n=4)\end{array}$ & $0 \cdot 25(0 \cdot 3)$ & $64 \cdot 5(22 \cdot 2)$ & $0.25(0.3)$ & $1 \cdot 0(0 \cdot 7)$ & 0 \\
\hline Normal volunteers $(n=10)$ & $1 \cdot 10(0 \cdot 5)$ & $82 \cdot 0(3 \cdot 4)$ & $2 \cdot 0(0 \cdot 8)$ & $1 \cdot 2(0 \cdot 3)$ & $1 \cdot 0(0 \cdot 1)$ \\
\hline Sarcoid patients $(n=15)$ & $0.9(0 \cdot 2)$ & $96.0(1 \cdot 0)$ & $10 \cdot 0(0 \cdot 5)^{\star}$ & $5 \cdot 0(0 \cdot 9)^{\star}$ & $3 \cdot 0(0 \cdot 3) \dagger$ \\
\hline
\end{tabular}

cells in any of the groups. In those primary biliary cirrhosis patients without lymphocytosis, a greater proportion of macrophages were RFD7+ (Table IV).

\section{RELATIONSHIP OF BRONCHOALVEOLAR LAVAGE DATA TO BIOLOGICAL AND HISTOLOGICAL STAGING}

The normal range for serum bilirubin level in our study was taken as $5-17 \mathrm{mmol} / \mathrm{l}$. Six of our patients with primary biliary cirrhosis had hyperbilirubinaemia, of whom only two showed a lymphocytosis in their lavage. All the remaining four patients with lymphocy tosis had normal serum bilirubin levels. (Table V).

Only one of our primary biliary cirrhosis patients had early disease on liver biopsy staging (stage 1); this patient had increased lymphocyte numbers in lavage. Four patients showed moderately advanced primary biliary cirrhosis (stage 2), three of whom had lymphocytosis. The remaining five primary biliary cirrhosis patients had late stage disease in their liver biopsies; only two of these patients had lymphocytosis (Table V).

\section{Discussion}

Our study has shown that a proportion of patients with primary biliary cirrhosis develop subclinical alveolitis. The alveolitis is charac-

TABLE IV Distribution of macrophage subsets in bronchoalveolar lavage of primary biliary cirrhosis patients compared to normal and sarcoid subjects

\begin{tabular}{llll}
\hline & $R F D I$ & $R F D 7$ & $R F D 9$ \\
\hline $\begin{array}{l}\text { Primary biliary cirrhosis } \\
\text { with lymphocytosis }(\mathrm{n}=6)\end{array}$ & $31 \cdot 2(1 \cdot 9)^{\star}$ & $38 \cdot 1(5 \cdot 7)^{\star}$ & $51 \cdot 7(1 \cdot 6)$ \\
$\begin{array}{l}\text { Primary biliary cirrhosis } \\
\text { without lymphocytosis }(\mathrm{n}=4)\end{array}$ & $6 \cdot 5(1 \cdot 1)$ & $93 \cdot 0(1 \cdot 6) \dagger$ & $50 \cdot 7(2 \cdot 1)$ \\
$\begin{array}{l}\text { Normal volunteers }(\mathrm{n}=10) \\
\text { Sarcoid (n=15) }\end{array}$ & $13 \cdot 6(2 \cdot 1)$ & $20 \cdot 2(1 \cdot 5)$ & $48 \cdot 2(1 \cdot 6)$ \\
& $46 \cdot 3(5 \cdot 1)^{\star}$ & $30 \cdot 4(6 \cdot 4)$ & $45 \cdot 0(1 \cdot 0)$
\end{tabular}

All figures above represent percentage of total number of morphologically identifiable macrophages (mean (SE)). ${ }^{\star} \mathrm{p}=<0.001$ compared with normal; $\uparrow \mathrm{p}=<0.0001$ compared with normal

TABLE V Correlation of bronchoalveolar lavage lymphocytosis with staging of primary biliary cirrhosis

\begin{tabular}{llllll}
\hline Patient & Sex & Age & $\begin{array}{l}\text { Liver biopsy } \\
\text { stage }\end{array}$ & $\begin{array}{l}\text { Serum bilirubin } \\
(\mu \mathrm{mol})\end{array}$ & \% Lavage lymphocytosis \\
\hline 1 & F & 52 & 1 & 30 & 19 \\
2 & $\mathrm{~F}$ & 68 & 2 & 12 & 35 \\
3 & $\mathrm{M}$ & 56 & 2 & 44 & 36 \\
4 & $\mathrm{~F}$ & 67 & 2 & 8 & 28 \\
5 & $\mathrm{~F}$ & 65 & 2 & 20 & 2 \\
6 & $\mathrm{~F}$ & 42 & 4 & 17 & 35 \\
7 & $\mathrm{M}$ & 53 & 4 & 11 & 13 \\
8 & $\mathrm{~F}$ & 57 & 4 & 93 & 6 \\
9 & $\mathrm{~F}$ & 54 & 4 & 86 & 1 \\
10 & $\mathrm{~F}$ & 71 & $3 / 4$ & 24 & 10 \\
\hline
\end{tabular}

terised by an increased number of activated Thelper lymphocytes with a concomitant increase in the proportion of non-lymphoid cells with the phenotype of antigen presenting cells, despite an overall fall in macrophage proportion. This increase was associated with a reduction in the proportion of RFD7+ cells. This might imply a switch from one phenotype to the other; a situation seen to occur in sarcoidosis and related to potential changes in macrophage function. ${ }^{29}$ Together with the presence of lymphocytosis these findings reflect the distribution of cells in bronchoalveolar lavage of patients with active pulmonary sarcoidosis reported previously..$^{30}$ The proportion of cell subsets in primary biliary cirrhosis patients without evidence of a lymphocytosis reflect those of normal subjects.

Apart from one other study, all investigations into primary biliary cirrhosis associated lung involvement have only focused on radiological and pulmonary function assessment in patients who tended to be symptomatic. Our patients were asymptomatic, with clear chest radiographs and normal lung function, yet with evidence of an alveolitis in their bronchoalveolar lavage. Five of these six patients with bronchoalveolar lavage lymphocytosis were found to have abnormal computed tomography scans of thorax, with posterior lower zone crescentic shadowing; while four of these patients also had abnormal DPTA clearance. ${ }^{31}$ All four primary biliary cirrhosis patients without lymphocytosis had normal computed tomography scans and DTPA scans and DTPA clearance. Such observations confirm that primary biliary cirrhosis patients can indeed develop latent pulmonary involvement during the course of their liver disease.

Our results concur with Wallaert et al ${ }^{12}$ that the alveolar inflammation found in asymptomatic primary biliary cirrhosis patients is characterised by $\mathrm{T}$-lymphocytes and activated marcrophages. Wallaert's study found no relationship between the lung lymphocytosis and duration or stage of the primary biliary cirrhosis. The results presented here also fail to show such a relationship. These observations could possibly be explained by the fact that the degree of lymphocytosis in bronchoalveolar lavage may itself be decreased in advanced fibrotic disease. ${ }^{13}$ Indeed, the absence of alveolitis in bronchoalveolar lavage in advanced primary biliary cirrhosis patients should not discount the possible presence of disease in their lung tissue. In our study however the three advanced primary biliary cirrhosis patients with normal bronchoalveolar lavage cell counts had normal computed tomography scans and DTPA clearance.

As a control group of non-PBC liver disease patients was not included in our study, it could be argued that the observed alveolitis in primary biliary cirrhosis patients is non-specific and secondary to liver damage. Previous authors, however, have shown the lavage of patients with non-primary biliary cirrhosis liver disorders such as alcoholic cirrhosis reflects that of normal volunteers. ${ }^{12}$ The alveolitis observed in primary biliary cirrhosis is also unlike that found in the 
lavage of patients with pulmonary viral infection, in whom there is an increase in the proportion of CD8 + T-lymphocytes as well as B-cells, with no change in the non-lymphoid population [submitted data].

Rodriguez-Roisin et $a l^{32}$ concluded that the observed lung disease in primary biliary cirrhosis patients was probably the result of associated Sjögren's syndrome; yet none of our primary biliary cirrhosis patients had any associated clinical disease. As no lung biopsies were performed in our study (patients were asymptomatic with clear CXR), it may seem that our data only reflect the existence of an inflammation in the lower respiratory tract, and therefore do not necessarily represent interstitial lung involvement. It is now accepted, however, that the initial lesion in granulomatous lung disorders is an alveolitis, which may proceed to granuloma formation within the parenchyma. ${ }^{14}$ Campbell et al showed that bronchoalveolar lavage analysis reflects the heterogeneity of the mononuclear inflammatory cell infiltrate in tissue biopsies. ${ }^{30}$ Indeed, a mononuclear alveolitis has previously been reported in association with interstitial granulomata in some symptomatic patients with primary biliary cirrhosis.

Our results may be interpreted as a reflection of systemic changes - that is, as simply reflecting peripheral blood ratios. Although this study did not investigate peripheral blood lymphocyte subsets, previous authors have demonstrated that bronchoalveolar lavage lymphocyte findings in primary biliary cirrhosis patients do not bear any correlation to comparative peripheral blood markers. ${ }^{12}$ Even if the former were the case, the lymphocytosis observed in the lungs of a major proportion of the primary biliary cirrhosis patients at best suggests a subclinical alveolitis, and at worst a nascent pneumonitis.

Our data show that the characteristics of the latent lung involvement in primary biliary cirrhosis can be similar to those found in sarcoidosis. There is in fact considerable clinical and histological overlap in primary biliary cirrhosis and sarcoidosis.' Immunologically, both show evidence of skin anergy, ${ }^{33}$ delayed type hypersensitivity reactions, ${ }^{5}$ and increased HLA-DR expression on effector mononuclear cells. ${ }^{34}$ Indeed, there have been reports of the possible coexistence of both sarcoidosis and primary biliary cirrhosis in the same patient. ${ }^{35}$

The presence of aberrations within the lymphoid and non-lymphoid cell populations in the bronchoalveolar lavage of some asymptomatic primary biliary cirrhosis patients raises the possibility of an emergence of granuloma producing mechanisms in the lung similar to those active in the liver; and consistent with what has previously been observed in other granulomatous lung disorders such as sarcoidosis. ${ }^{14}$

We are grateful to Professor Peter Scheuer, who provided the liver biopsy results. This study has been supported in part by a grant from Draco Laboratories, Lund, Sweden.

Scheuer PJ. Primary biliary cirrhosis. Proc $R$ Soc Med 1967; 60: $1257-60$.

2 Christensen E, Crowe J, Doniach D. Clinical pattern and course of disease in primary bilary cirrhosis based on an analysis of 236 patients. Gastroenterology 1980; 78: 236-46. 3 Shapiro JM, Smith H, Schaffner F. Serum bilirubin, prognostic factor in primary biliary cirrhosis. Gut 1979; 20 $137-40$

4 Scheuer P. Liver biopsy interpretation. Baltimore: Williams \& Williams, 1973: 33-8.

5 Kaplan MM. Primary biliary cirrhosis. Adv Intern Med 1987 32: 359-77.

6 James SP, Hoofnagle JH, Strober W. Primary biliary cirrhosis. A model autoimmune disease. Ann Intern Med 1983; 99. 500-12.

7 Sherlock S, Scheuer PJ. The presentation and diagnosis of 100 patients with primary biliary cirrhosis. N Engl f Med 1973; 289: 674-8.

8 Turner-Warwick $M$. Fibrosing alveolitis and chronic liver disease. OF Med 1968; 37: 133-49.

9 Stanley NN, Fox RA, Whimster WF, Sherlock S, James DG Primary biliary cirrhosis or sarcoidosis - or both $N$ Engl $\mathcal{F}$ Med 1972; 287: 1282-4.

10 Golding PL, Smith M, Williams R. Multisystem involvement in chronic liver diseases. Am F Med 1973; 55: 772-82.

11 Stanley NN, Woodgate DJ. Mottled chest radiograph and gas transfer defect in chronic liver disease. Thorax 1972; 27: 315-23.

12 Wallaert B, Bonniere P, Prin L, Corlot A, Ponnel A, Voisin C. Primary biliary cirrhosis. Subclinical inflammatory alveolitis in patients with normal chest roentgenograms. Chest 1986; 90: 842-8.

13 Keogh BA, Crystal RG. Alveolitis - the key to the interstitial lung disorders. Thorax 1982; 37: 1-10.

14 Hunninghake GW, Garrett KC, Richerson HB, et al. Pathogenesis of the granulomatous lung diseases. Am Rev Pathogenesis of the granulor

15 Fulmer JD. An introduction to the interstitial lung diseases. Clin Chest Med 1982; 3: 457-65.

16 Unanue ER. Antigen presenting function of the macrophage. An Rev Immunol 1984; 2: 395-403.

17 Biondi A, Rossing TH, Bennett J, Todd RF. Surface membrane heterogenity among human mononuclear phagocytes. F Immunol 1984; 132: 1237-43.

18 Reynolds HY, Newball HH. Analysis of proteins and respiratory cells obtained from human lungs by bronchial lavage. F Lab Clin Med 1974; 84: 559-73.

19 Janossy G, Bofill M, Poulter LW, et al. Separate ontogeny of two macrophage-like accessory cell populations in human fetus f Immunol 1986; 136: 4354-7.

20 Poulter LW, Campbell DA, Munro C, Janossy G. Dicrimination of human macrophages and dendritic cells by Dicrimination of human macrophages and dendritic cells by means

21 Munro CS, Campbell DA, Collings LA, Poulter LW. Monoclonal antibodies distinguished macrophages and epithelioid cells in lesions of sarcoidosis and leprosy. Clin Exp Immunol 1987; 68: 282-7.

22 Bach MA, Phan-Dinh-Tuy F, Bach JF, et al. Unusual phenotype of human inducer $\mathrm{T}$ cells as measured by $0 . \mathrm{KT} 4$ and related monoclonal antibodies. F Immunol 1981; 127: 908-13.

23 Janossy G, Bofill M, Poulter LW. Two colour immunofluorescence: analysis of the lymphoid system with monoclonal antibodies. In: Van Noorden S, Polak J, eds Immunocytochemistry today: Oxford: Wright, 1985.

24 Poulter LW, Duke O, Panayi GS, et al. Activated T lymphocytes on the synovial membrane in rheumatoid lymphocytes on the synovial membrane in rheumatoid 23-9.

25 Uchiyama T, Broder S, Waldmann TA. A monoclonal antibody (anti-Tac) reactive with activated and functionally mature human T cells. Production of anti-Tac monoclonal antibodies and distribution of Tac positive cells. 7 Immuno 1981; 126: 1393-7.

26 Munro CS, Campbell DA, duBois RM, et al. Suppression associated lymphocyte markers in lesions of sarcoidosis. Thorax 1988; 43: 471-4.

27 Smith SH, Brown MH, Rowe D, et al. Functional subsets of human helperinducer cells defined by a new monoclona antibody, UCHL1. Immunology 1986; 58: 63-70.

28 Mason DY Abdulaiz Z, Falini B, Stein H. Double immunoenzymatic labelling. In: Polak J Van Noorden S eds. Immunocytochemistry: practical applications in pathology and Immunocytochemistry: practical applications in

29 Spiteri MA, Clarke SW, Poulter LW. Phenotypic and functional changes in alveolar macrophages contribute to the pathogenesis of pulmonary sarcoidosis. Clin Exp Immuno 1988; 74: 359-64.

30 Campbell $\mathrm{Da}$, Poulter LW, duBois RM. Immunocompeten cells in alveolar lavage reflect the cell populations in transbronchial biopsies in pulmonary sarcoidosis. Am Rev Respir Dis 1985; 132: 1300-6.

31 Johnson MA, Spiteri MA, Epstein O, et al. Subclinica alveolitis in patients with primary biliary cirrhosis. Eur Respirf 1988; 1: 246 .

32 Rodriguez-Rosin R, Pares A, Bruguera M, Coll J, Picado C, Augusti-Vidal A. Pulmonary involvement in primary cirrhosis. Thorax 1981; 36: 208-12.

33 Fox RA, James DG, Scheuer PJ, et al. Impaired delayed hypersensitivity in primary biliary cirrhosis. Lancet 1969; hypersens

34 Colussi $G$. In situ characterisation of cell surface antigen of the mononuclear cell infiltrate and bile duct epithelium in PBC. mononuclear cell infiltrate and bile

35 Fagin EA, Moore-Gillon JC, Turner-Warwick M. Multiorgan granulomas and mitochondrial antibodies. $N$ Engl $\mathcal{F}$ Med 1983; 308: $572-5$. 